\title{
Europe's lifelong learning markets, governance and policy: Using an
}

instruments approach. Milana, M., G. Klatt, \& Vatrella, S. (eds). (2020) Palgrave Studies in Adult Education and Lifelong Learning, Palgrave Macmillan. ISBN 978-3030-38068-7.

Ever since 1992, when Jacques Delors' European Commission White Paper on competitiveness made the argument that the solution both for Europe's future economic prosperity and for its social cohesion rested with lifelong learning, the European Commission and later European Union has had to manage developments to strengthen European co-operation knowing that whilst vocational skills and training fell within the EU's remit, education - including the education of adults remained the responsibility of nation states. In addition, lifelong learning, and for that matter adult education, has fuzzy boundaries, with formal, non-formal and informal learning all playing a part. Lifelong learning has multiple actors at state, regional and local level; private sector and third sector participants, and a continuum ranging from wholly state funded to user paid provision. Adults' motivations for engaging in learning vary widely, and there are differences in how younger and older adults participate. At the level of the nation state, adult education policy is often split between different ministries, with the interests of adult learners often marginal to the central policy concerns of each ministry. Again, in federal states and in devolved administrations, different views on priorities ensue.

In response to the challenges in securing common policies arising from this complicated picture, the EU has sought to co-ordinate the multiple and complex policies in the field by developing strong policy co-ordination to manage the diverse clusters of public and private interactions, and the variety of actors engaged. It is the central concern of 'Europe's Lifelong Learning Markets, Governance and Policy' to explore the efficacy and impact of the EU's initiatives in the education of adults. To that end, this richly detailed book (one product of the EU funded ENLIVEN project) examines the governance mechanisms and policy instruments deployed by the EU, and reports on eight national case studies by internationally recognised authors, which take the example of the European Youth Guarantee to explore the impact of the policy in different EU states.

In their introductory chapter, Marcella Milana and Gosia Klatt explain their rationale for adopting an instruments approach, as an effective tool for examining policy mixes, where diverse actors impact on the extent and success of policy implementation. They identify four governance mechanisms (standard setting, capacity building, 'elite-learning', and financial redistribution), and five policy instruments (co-ordinated working groups/networks, mutual and peer-learning arrangements, data generation, benchmarks, and funding schemes) used by the EU in co-ordinating policy and its adaptation to the circumstances in nation states. The book is divided into two parts - the first seven chapters exploring European 
governance and policy co-ordination, affecting lifelong learning (and adult education in particular). There are chapters on the EU's 'Education and Training 2020' initiative; the Renewed European Agenda on Adult Learning, the European Youth Strategy, and on the European Semester (which has the intriguing sub-title 'How does it work? Why does it matter?), and chapters looking at tools for peer review and evaluating Europe's lifelong learning systems, and on the Upskilling Pathway. Taken together the chapters show how the formal policy making mechanisms of the EU, involving Member States, the European Parliament, the Committee of the Regions, and Business and Trades Unions -are supplemented by networks of practitioners, policy experts engaged in policy formation and review, and by advocacy organisations supported by the EU to act as critical friends. The effect of the combination of actors engaged, and the interweaving of policy initiatives, has been to create a European community of adult education, created from the often fragmented and marginal position practitioners and policy advocates have within national policy. Not all the co-ordinating tools have had comparable success. In the light of the financial crisis in 2007-8, the European Council adopted a participation target for adults' learning of 15 percent by 2020, from a base of 9 percent in 2008. Yet progress has been glacial - with just 11.1 percent engaging in 2018. Generating data and setting targets can only do so much, if the political will to match transnational agreements with practical policy implementation on the ground. Whilst the EU priorities continue to assert the twin goals of economic competitiveness and social inclusion, it is those dimensions of adult learning closest to the interests of labour markets that dominate, as neoliberal policies have swept through the Community. Lifewide learning, in many countries, has been on the retreat - despite the support of the Commission.

The second part of the book, which comprises eight accounts of the extent and effectiveness of such domestic adaptation by taking a single policy initiative, the European Youth Guarantee, which was developed in response to soaring levels of youth unemployment in the EU, in a representative range of Member States Estonia, Slovakia, Bulgaria, Spain, Italy, Austria, Belgium, Denmark and England and Scotland within the United Kingdom. The chapters present a continuum between countries reliant on the EU initiative to kick start a policy focus previously absent (as in Bulgaria for example), to those, like Denmark where the Guarantee merely reinforces existing practice, and represents some welcome supplementary funding. The initiative produce institutional change - for example in Italy the EYG was used to create an agency, ANPAL, able to work across sectors to support and co-ordinate active labour market activities, whilst in Spain (the largest beneficiary of EU funding) through the Youth Guarantee the Ministry of Labour, Migration and Social Security emerged as a key policy actor in adult education. In Austria, the policy was seen as a stimulus to the wider development of adult education policy, yet as Hefler and Steinheimer observe : 'Government administrators often have the goal of ensuring that no available EU funding remains unused and anyone helping to achieve this goal might be celebrated 
(p345)', whilst noting that the use of EU funding needs to be seen within much wider struggles among competing policy fields. A number of the country studies report a failure to reach the most marginalised; others report the focus of domestic adaptation focused almost exclusively on work placement, with little educational engagement; and Milana and Klatt conclude that the opportunity presented by the EYG to link young adult policy to wider adult education policy was not addressed. Despite this, the overall picture presented in the national studies is of the benign impact of the initiative, and the study as a whole shows that through the multiplicity of governance and policy instruments adopted, the EU has a positive impact on lifelong learning policy in the nation states - albeit with that impact in most visible in the less developed economies. As Howard Stevenson reflects, in one of five celebratory endorsements at the front of the book, despite education policy being 'a matter of national competence for Member States to determine...co-ordinating cross-EU education policy is an area where an often times troubled institution has demonstrated some of its most significant impact (p.xx).'

The genesis of the study in a European Union transnational project perhaps explains the forensic level of detail offered in each of the studies - sometimes at the price of a clear narrative and analytical flow. In addition, I missed some account of the other major policy forces affecting national policy in the field perhaps most notably the influence of OECD and its PIAAC survey and resultant country studies. I think, too, that the volume would have benefited from tighter proof reading. To take just two examples, we are told that in Belgium ' the NEET rate was $9.2 \%$ in 2018, which is higher than the EU average of $10.4 \%$ (p344)', and elsewhere that the same country allocated shares of expenditure both at just over the minimum allocated share, and also that it allocated more than double(p178). Only later do we workout that this must refer to separate federated responses from the same state.

Nevertheless, despite these caveats, the book makes a significant and rigorous contribution to policy studies in the field of adult education, for which the team of authors are to be congratulated.

Alan Tuckett

Professor Sir Alan Tuckett is Emeritus Professor of Education at the University of Wolverhampton, and Honorary Fellow of UIL. 
